\title{
Applying Isotope Techniques and Modeling to Identify the Nitrogen Source in Göksu Delta
}

\author{
Olcay Gülçiçek*, Zeynel Abidin Demirel \\ Department of Environmental Engineering, Faculty of Engineering, Mersin University
}

Received: 30 April 2018

Accepted: 16 August 2018

\begin{abstract}
Göksu Delta is an important wetland area in Turkey and has been declared a first-degree site and has been included in the Ramsar list. Agricultural activities continue for 12 months of the year due to the favorable climate in the delta and these activities are the most important income source for the people living in the region. Investigations to date have identified the presence of nitrogen pollutants in delta groundwater. However, studies have yet to be conducted on the source of nitrogen contaminants. This study has identified source(s) of nitrogen through the combined use of isotope methods and groundwater modeling. ${ }^{15} \mathrm{~N}$ and ${ }^{18} \mathrm{O}$ stable isotope analysis were done for identifying the source(s) of nitrogen pollution. We used a three-dimensional Visual MODFLOW model to simulate the alluvial aquifer around the delta. After establishing the groundwater fate and transport model (MT3DMS), we investigated the source of nitrate pollution by particle tracking analyses (MODPATH). The results of $\delta 15 \mathrm{~N}$ showed that nitrogen in delta groundwater was greatly affected by agricultural activities, but was mainly sourced from domestic wastewater. Similar to isotopic results with the particle tracking model, 5 years ago it was determined that nitrate ions came from domestic wastewater of Silifke city and surrounding settlements that lack wastewater treatment facilities.
\end{abstract}

Keywords: Göksu Delta; groundwater modeling; nitrogen sources; stable isotope technique

\section{Introduction}

Wetlands that cover $6 \%$ of the world's land surface contain about $12 \%$ of the global carbon pool, and therefore the contribution of wetlands to the global carbon cycle is great $[1,2]$. Wetlands have countless benefits as they provide humankind, nutrition and building materials, biodiversity, flood control,

*e-mail: olcayozer@mersin.edu.tr groundwater recharge, and climate change mitigation. Governments and other institutions have tried to conserve and protect wetlands for more than 40 years, since the Ramsar Convention. Many wetlands have close associations with groundwater. For example, a wetland could feed the aquifer or could be fed from the aquifer. In such cases, the water budget of the aquifer and the health of the wetland ecosystem are connected. So, water resources and wetlands must be managed in an integrated manner in order to ensure the sustainability of the ecosystem [3]. 
Groundwater quality is affected by agricultural activities, uncontrolled wastewater discharges, and excessive municipal and industrial use [4, 5]. The Environmental Protection Department of the Ministry of Environment of Turkey declared Göksu Delta a Special Environmental Protection Zone in 1990. Additionally, since 1994 the delta has been designated as a Wetland of International Importance Class A, according to the Ramsar Convention. Agriculture is the most important source of income for people living in the region. In previous studies it was detected that increasing agricultural activities negatively affect the quality of water resources in the delta [6-8].

\section{Description of the Study Area}

Göksu Delta, the most important wetland of the Middle East and Europe, is on the southern edge of the Silifke District of Mersin Province, which is located on the edge of middle Taurus (Fig. 1). It consists of sediments that were carried by the Göksu River, which separates the delta into two parts. The typical Mediterranean climate is dominant in the region, which is characterized by dry and warm/hot summers and cool/mild and wet winters [9]. The delta consists of alluvial accumulations (500-700 $\mathrm{m}$ depth from the surface) so that the delta aquifer is generally an unconfined aquifer. The alluvial aquifer consists of a heterogeneous mixture of gravel, sand, silt, clay, and sandy-clay. The delta has more than 1000 wells, but most of the wells in the area have not overtaken the alluvial unit [8]. Due to the climatic characteristics of the region, approximately 10,000 hectares in the delta are being cultivated each month of the year. Most products that are grown in the delta are citrus fruits, strawberries, tomatoes, wheat, and rice. Fig. 1 shows the pattern of agricultural products of Göksu Delta, Special Environmental Protection Area (SEPA).

As a result of intensive agricultural activities, annual fertilizer use in the area is much higher than the national average [10]. In this study, technicians, farmers, and pesticide dealers were interviewed from the District Directorate of Agriculture, resulting in a table on the use of pesticides and fertilizers in the delta (Table 1). This map (Fig. 1) and table (Table 1) helped to interpret the results of the groundwater.

\section{Nitrogen Isotopes as Environmental Tracers}

Nitrogen is a vital element due to the fact that it exists in the structure of proteins, nucleic acids, hormones, and vitamins that are important for living things [11]. Nowadays, nitrogen pollution is a serious threat to both ground and surface waters. The most common nitrogen contaminant sources are agricultural activities, septic tanks, industrial and domestic wastewaters, and
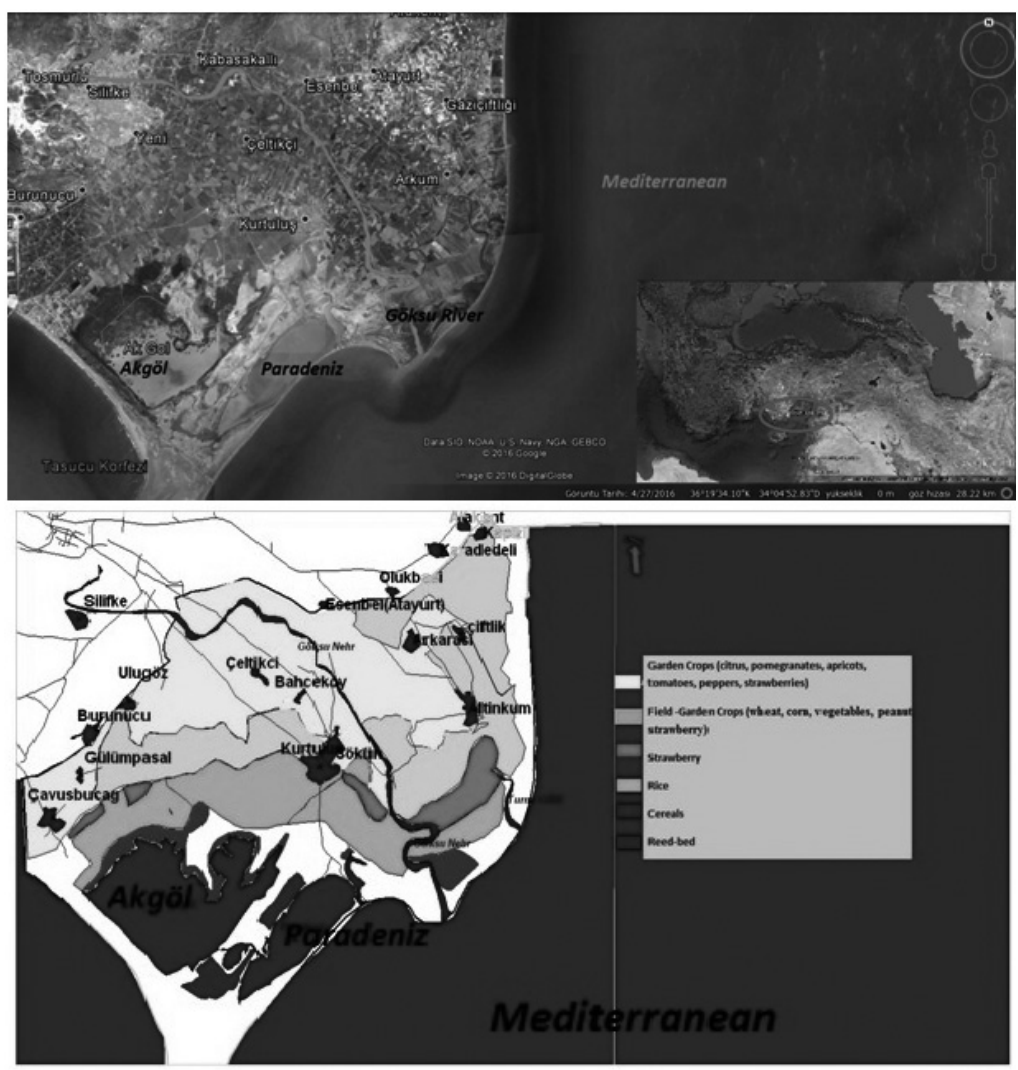

Fig. 1. Göksu Delta and agricultural products map [9] (blue: garden crops (citrus, pomagranates, aprikots, tomatoes, peppers, strawberries), orange: garden crops 2 (wheat, corn, vegetables, peanuts, strawberries), pink: strawberries, light green: rice, dark green: cereals, brown: reed-bed). 
Table 1 . The most commonly used fertilizers and pesticides by months in Göksu Delta.

\begin{tabular}{|c|c|c|c|c|c|c|c|c|c|c|c|c|}
\hline & \multicolumn{12}{|c|}{ Months } \\
\hline Commonly used fertilizers and pesticides & 1 & 2 & 3 & 4 & 5 & 6 & 7 & 8 & 9 & 10 & 11 & 12 \\
\hline $\mathrm{NH}_{4}-\mathrm{NO}_{3}$ & & & & & & & & * & $*$ & $*$ & $*$ & $*$ \\
\hline $\mathrm{NH}_{4}-\mathrm{SO}_{4}$ & & & & & & & & & & & & \\
\hline Phosphorus Fertilizer & & & & & & & & & * & * & * & \\
\hline $\mathrm{FeSO}_{4}$ & & & & & & & * & & & & * & \\
\hline Fetrilon combi-2 & & & & & & & & & & & & \\
\hline (Mn-Fe-S-Zn-Cu-Mo-B) & & & & & & & & & & & & \\
\hline Active ingredient: Abamectin 18g/L-TORPEDO EC & & & & & * & * & & & & & & \\
\hline Active ingredient:acetonitrit- HEKPLON 20 SP (insecticide) & & & & & * & * & & & & & & \\
\hline Active ingredient:pyriproxfen-100gr/L-ADMİRAL 10EC & & & & & & & * & & & & & \\
\hline Iron fertilizer -consist of Ferrostrene- $4.8 \%$ ortho-ortho . & & & * & * & & & & & & & & \\
\hline TORPEDO- (insecticide) + DOMARK (fungicide) & & & * & * & * & & & & & & & \\
\hline KODEFOL 680 (consist of phosphorus ) & & & * & * & * & & & & & & & \\
\hline Chlorine profosel ethyl (nematocide) & & & & & & & * & & & & & \\
\hline
\end{tabular}

power plants [12-15]. Isotopes are chemical elements that have the same atomic number but different atomic mass. The chemical identity of an atom is determined by its atomic number [16, 17]. Nitrogen has two stable isotopes, Nitrogen-14 and 15. Stable isotopes have been used effectively in monitoring the fate of pollutants and determining the source of pollutants (from animal waste, septic systems, sewage treatment plants, etc.) in the ecosystem [18-27].

This is possible for a variety of reasons, including: Waters originating at different times and locations often have distinctive isotopic compositions; environmental isotopes are not normally considered to react significantly with catchment materials; and changes in solute isotopic ratios generally occur in predictable and recognizable directions, allowing them to be reconstructed from isotopic compositions [28].

Stable isotope data are reported as "delta $(\delta)$ values" or per mil values (\%), which is shorthand for parts per thousand. Nitrogen isotopic compositions as $\delta^{15} \mathrm{~N}$ are calculated by the following equation (1);

$\delta{ }^{15} \mathrm{~N}(\%)=\left[\left(\left({ }^{15} N /{ }^{14} N\right)_{\text {sample }} /\left({ }^{15} N /{ }^{14} N_{\text {air }}\right)\right)-1\right] x 1000$

Positive $\delta^{15} \mathrm{~N}$ value $\left(\delta^{15} \mathrm{~N}\right.$ greater than 0$)$ means that the sample has a higher ${ }^{15} \mathrm{~N} /{ }^{14} \mathrm{~N}$ ratio than the atmosphere standard. Negative $\delta^{15} \mathrm{~N}$ value $\left(\delta^{15} \mathrm{~N}\right.$ less than 0) means that the sample indicates a lower ${ }^{15} \mathrm{~N} \quad{ }^{14} \mathrm{~N}$ ratio than the atmosphere standard [29]. The majority of $\mathrm{N}$ in the atmosphere is composed of ${ }^{14} \mathrm{~N}(99.6337 \%)$, and the remainder is composed of ${ }^{15} \mathrm{~N}(0.3663 \%)$ [30].

The identification of nitrate pollution sources are of prime importance for better management of groundwater resources. Groundwater $\delta^{15} \mathrm{~N}$ values vary depending on the contaminant source [16, 29-33]. The nitrogen isotope ratio values were first used for identifying the sources of nitrate contamination in the 1970s. This method is difficult due to the complexity of nitrate pollution and groundwater systems [34]. Although it has been accepted as an effective tool for contaminant source identification in the science world since the 1970s [35, 36], the use of this method is still not common [36].

At the beginning of the 1990s it was proposed the concomitant use of the stable nitrogen isotope $\left({ }^{15} \mathrm{~N}\right)$ and stable oxygen isotope $\left({ }^{18} \mathrm{O}\right)$ in the nitrate compound were applied for groundwater studies [37].

The dual isotope approach involves determining both nitrogen and oxygen isotopic compositions and it has three important benefits [28];

1. It is better to use with two tracers in the source identification study, since the isotopic oxygen isotope spread $\left(\delta^{18} \mathrm{O}\right)$ of some pollutant sources is greater than the nitrogen isotopes $\left(\delta^{15} \mathrm{~N}\right)$ spread.

2. Some nitrate sources that are presently indistinguishable with $\delta^{15} \mathrm{~N}$ alone (e.g., fertilizer vs. soil nitrate, or atmospheric vs. soil nitrate) may be identified once $\delta^{18} \mathrm{O}$ values are incorporated.

3. The isotopic compositions of oxygen of the nitrate systematically vary with nitrogen isotopic compositions during denitrification. Indeed, in systems where the dominant nitrate sources are isotopically distinguished, the source contributions (in theory) can be determined despite significant amounts of denitrification [28, 38].

The nitrogen isotope tracer method has increasingly been applied in many parts of the world [39]. Within a nitrate-nitrogen isotope tracing study, the pollution sources can be estimated by isotopic comparison 


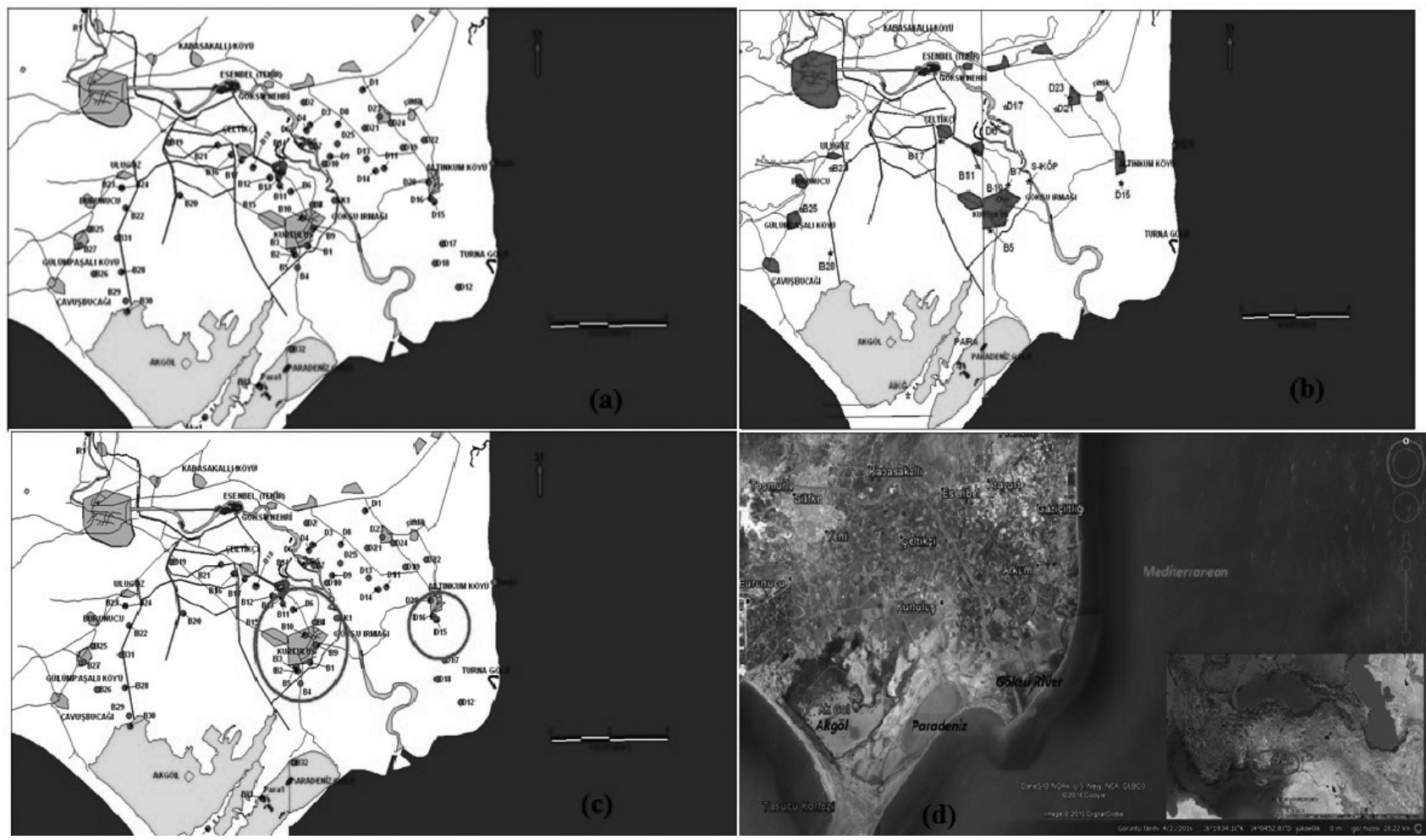

Fig. 2. a) Groundwater sample points in Göksu Delta b) Göksu Delta, surface groundwater sample points (only major ion analysis was investigated) c) groundwater samples location map for isotope analysis, and d) Göksu Delta map.

between the water samples and possible source materials [28].

Lindenbaum (2012) [11] investigated ammonia sources in Nam Du Hanoi groundwater using boron isotopes besides nitrogen isotopes. Li and others (2017) [40] reported that the nitrogen stable isotope method could be successfully used to distinguish between organic and synthetic nitrogen sources. In their study, Sebilo et al. (2013) [41] reported that mineralization, nitrification, and denitrification in the soil affected the ratio of $\delta^{15} \mathrm{~N}$ in groundwater. Hosono et al. (2013) [37] demonstrated that the use of nitrate isotope tracers efficiently improves with a comprehensive understanding of groundwater flow dynamics. Ma et al. (2016) [4] investigated nitrate pollution using ${ }^{15} \mathrm{~N}$ in the groundwater of northeastern China. The results of the study demonstrated that nitrate was derived from fertilizer and sewage in different periods.

Zhang et al. [42], by using a dual isotopic analysis of $\mathrm{NO}_{3}$, conducted a study in the North China Plain with the aim to identify nitrate pollution in both surface water and groundwater in irrigated agricultural regions. Zhang et al. [42] showed that the main sources of nitrate were nitrification of fertilizer and sewage in surface water, whereas groundwater sources during the dry season were mineralization of soil organic $\mathrm{N}$ and sewage. Savard et al. [43] analyzed the isotope ratios of the potential nitrate sources and measured the isotope and concentrations of nitrate in groundwater and surface water samples in the Wilmot River basin (PEI, Canada).
According to Savard et al. [43], elevated nitrate levels were coupled with agricultural activities and appeared to be most closely associated with extensive use of fertilizers for row crop production, rather than with other potential sources such as atmospheric load.

Many wetlands are hydrological and ecologically linked to adjacent groundwater bodies. Their interaction also affects the quality of each other. It is important to identify the source of pollution in terms of reducing and avoiding the effects of it. In previous studies, the presence of nitrogen pollution in the area was investigated, but the nitrogen source has never been identified in the Göksu Delta. This study aims to investigate the source of nitrogen pollution in groundwater in the Göksu Delta, a world-famous wetland that attracts attention in terms of groundwater quality in wetlands management. In this study, isotope techniques and groundwater modeling were used to identify the nitrogen source(s).

\section{Material and Methods}

\section{Sample Collection}

Groundwater samples were collected for chemical and isotopic analyses from 58 wells in February 2011 ( $1^{\text {st }}$ period wet season), July 2011 ( $2^{\text {nd }}$ period dry season), and September 2012 ( $3^{\text {rd }}$ period semi dry). At the same time, samples were taken from 5 points, i.e., Mediterranean Sea, Sökün Bridge, regulator, Paradeniz 


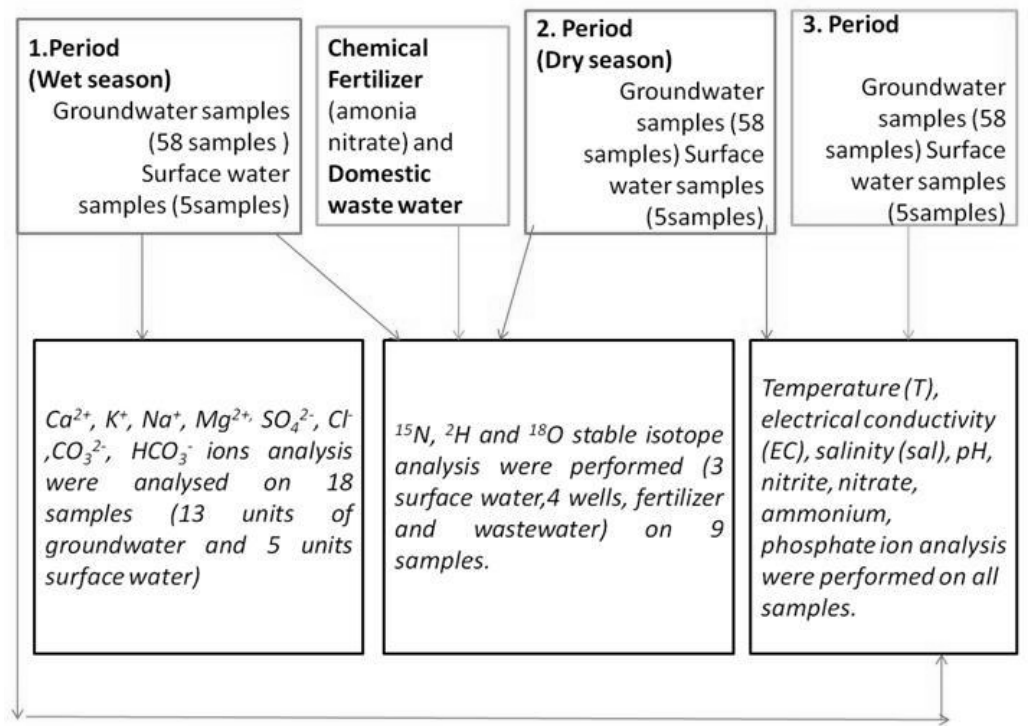

Fig. 3. Analysis process for all samples.

Lake, and Akgöl Lake, to determine the quality of surface water. The delta is divided into two parts by the Göksu River. The wells were named B code (west of the Göksu River) and D code (east of the river). According to "Water Pollution Control Regulations; Sampling and Methods of Analysis," water samples were taken from 58 wells. To determine the source of nitrate pollution in groundwater we took a chemical fertilizer sample (ammonium nitrate) and domestic wastewater sample. Ammonium nitrate fertilizer is used most widely in the study area in solid form, and it was analyzed in the form of aqueous solutions. The samples were stored at $4^{\circ} \mathrm{C}$ in a refrigerator until analyzed. The sample source points (wells) are shown in Fig. 2.

\section{Analytical Procedures}

Ammonium, nitrate, nitrite, phosphate and major ions analyses were carried out at the Environmental Engineering Department Laboratory of Mersin University, Mersin, Turkey. Isotope analysis was made by Iso-Analytical Ltd., a private stable isotope analysis laboratory in the UK. Analyses made in this period were described in Fig. 3. Measurements of electrical conductivity (EC), salinity (Sal), temperature (T), and $\mathrm{pH}$ were made in the sampled site using a $\mathrm{pH} / \mathrm{Cond} 340 \mathrm{i}$ WTW meter. Water samples for isotope analysis were obtained during wet and dry seasons from 4 wells and 3 points of surface waters (the Sökün River, the regulator, the Mediterranean Sea). Sample points and wells are shown in Fig. 2. Furthermore, to compare and determine nitrogen sources, the nitrogen isotope results were taken from the most widely used chemical fertilizers (ammonia nitrate) and domestic wastewater samples (Fig. 3). The isotope samples were measured against three reference standards. The first standard being IAR054 with $\delta^{2} \mathrm{H}_{\mathrm{V} \text {-SMOw }}=+4.93 \%$, the second IA-R052 with $\delta^{2} \mathrm{H}_{\mathrm{v} \text {-SMow }}=-157.12 \%$ and the third IA-R053 with $\delta^{2} \mathrm{H}_{\mathrm{VSMOW}}=-61.97 \%$. All three standards are traceable to the primary reference standards V-SMOW2 (ViennaStandard Mean Ocean Water) and V-SLAP2 (ViennaStandard Light Antarctic Precipitation) distributed by the IAEA. The IA-R054 standard was used as the reference to which the samples and other standards were measured. The IA-R052 standard was used for calibration of $\delta^{2} \mathrm{H}$, and the IA-R053 standard was used as a check of this calibration.

Cations $\left(\mathrm{Ca}^{2+}, \mathrm{K}^{+}, \mathrm{Na}^{+}\right.$, and $\left.\mathrm{Mg}^{2+}\right)$ were analyzed by inductively coupled plasma (ICP), and anions $\left(\mathrm{SO}_{4}{ }^{2-}, \mathrm{Cl}^{-}\right.$, $\mathrm{CO}_{3}^{2}$, and $\mathrm{HCO}_{3}^{-}$) were analyzed by ion chromatography (IC). Bicarbonates were determined by titration in the laboratory. Nitrite, nitrate, ammonium, and phosphate ions were measured with a Hanna C200 multiparameter photometer.

\section{Groundwater Modeling}

We used the Visual MODFLOW software for groundwater fate and pollution transport. Visual MODFLOW, originally released in 1994, is a groundwater modeling software program developed by Waterloo Hydrogeologic. All modeling studies have been summarized in the diagram below (Fig. 4). In order to model the transport of contaminants in groundwater, first it is necessary to establish the groundwater flow model.

\section{Results and Discussion}

\section{Hydrological Cycle in Göksu Delta}

The hydrologic cycle describes how water moves through the atmosphere, on the Earth surface, and 


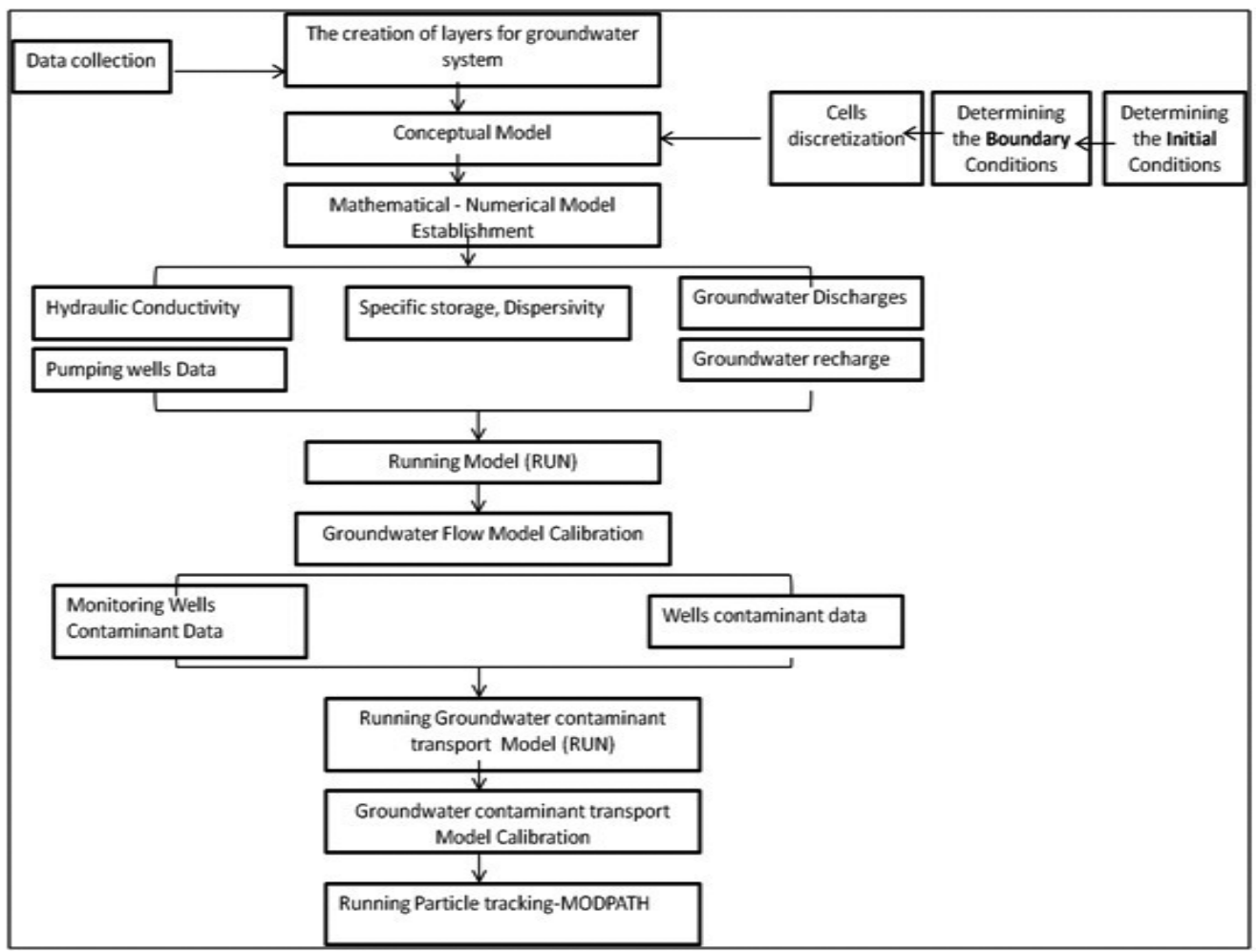

Fig. 4. Modeling process for Göksu Delta groundwater.

underground. For many years (1931-2003) climate statistics [7] were used to calculate the amount of the aquifer feeding Göksu Delta. In the study area, vegetation was accepted as well developed. A soil profile was created by examining the literature for this study (Table 2). Temperature, precipitation, and solar radiation graphs were created using the climate statistics of the study area by VHELP Model. Fig. 5 shows precipitation, temperature, and solar radiation values for the delta. Using meteorological data and the soil profile, an annual average $12.08 \mathrm{~mm}$ runoff, $372.15 \mathrm{~mm}$ evapotranspiration, and $72.72 \mathrm{~mm}$ groundwater feeding were calculated by the VHELP model.

\section{Groundwater Hydrogeochemistry in Göksu Delta}

AquaChem is a software package developed for graphical and numerical analysis and modeling of water quality data. Groundwater facies have been identified using Aquachem 5.1 software in this study. Taken from

Table 2. Göksu delta soil profile (created for the HELP Model).

\begin{tabular}{|c|c|c|c|}
\hline Layer & $\begin{array}{c}\text { Ceiling } \\
(\mathrm{m})\end{array}$ & $\begin{array}{c}\text { Floor } \\
(\mathrm{m})\end{array}$ & $\begin{array}{c}\text { Thickness } \\
(\mathrm{m})\end{array}$ \\
\hline$\square$ Fine sandy soil & 0.0000 & -0.3 & 0.3 \\
\hline$\because$ Coarse sandy loam & -0.3 & -0.8 & 0.5 \\
\hline E clay & -0.8 & -1.0 & 0.2 \\
\hline
\end{tabular}

the study area in the rainy season, 13 groundwater and 5 surface water sample points were transferred onto the digital map of the area, using MapInfo 9.5 GIS software according to the $x-y-z$ coordinates (Fig. 5). Major ion results of the 18 sample points are given below in Table 3. All values in the table were transferred to AquaChem program. Facies of the surface and groundwater, as a result of the data submitted into the AquaChem program, are shown in Table 4. The results were analyzed and the groundwater chemical characteristic (facies) determined the $\mathrm{Ca}-\mathrm{Mg}-\mathrm{HCO}_{3}{ }^{-}(\mathrm{B} 10, \mathrm{~B} 11, \mathrm{~B} 25, \mathrm{~B} 7)$ in the unpolluted area. In some wells, $\mathrm{Na}^{+}$and $\mathrm{Cl}^{-}$ions were observed due to seawater intrusion. In the literature [7, 44-48], it is presented that Paradeniz Lake is connected with the sea, and Akgöl Lake is connected with Paradeniz. The connection between them was once again revealed by anion-cation analysis, which is part of this study. According to the major ion analysis in Table 3, the thematic maps of surface and ground waters were created by using the MapInfo 9.5 program (Fig. 6).

When the map is analyzed, it is clearly seen that Paradeniz Lake has similar content to the sea. The predominant ion was bicarbonate in groundwater. The chloride ion was observed in almost each well. Excessive and unconscious use of wells led to seawater mixing in the Göksu coastal aquifers. In the study area, the chemical types of groundwater expected to be $\mathrm{Ca}$ $\mathrm{Mg}-\mathrm{HCO}_{3}$ due to the occurrence of seawater mixing it changed, and as a result, the $\mathrm{Na}^{+}$and $\mathrm{Cl}^{-}$ions were added 


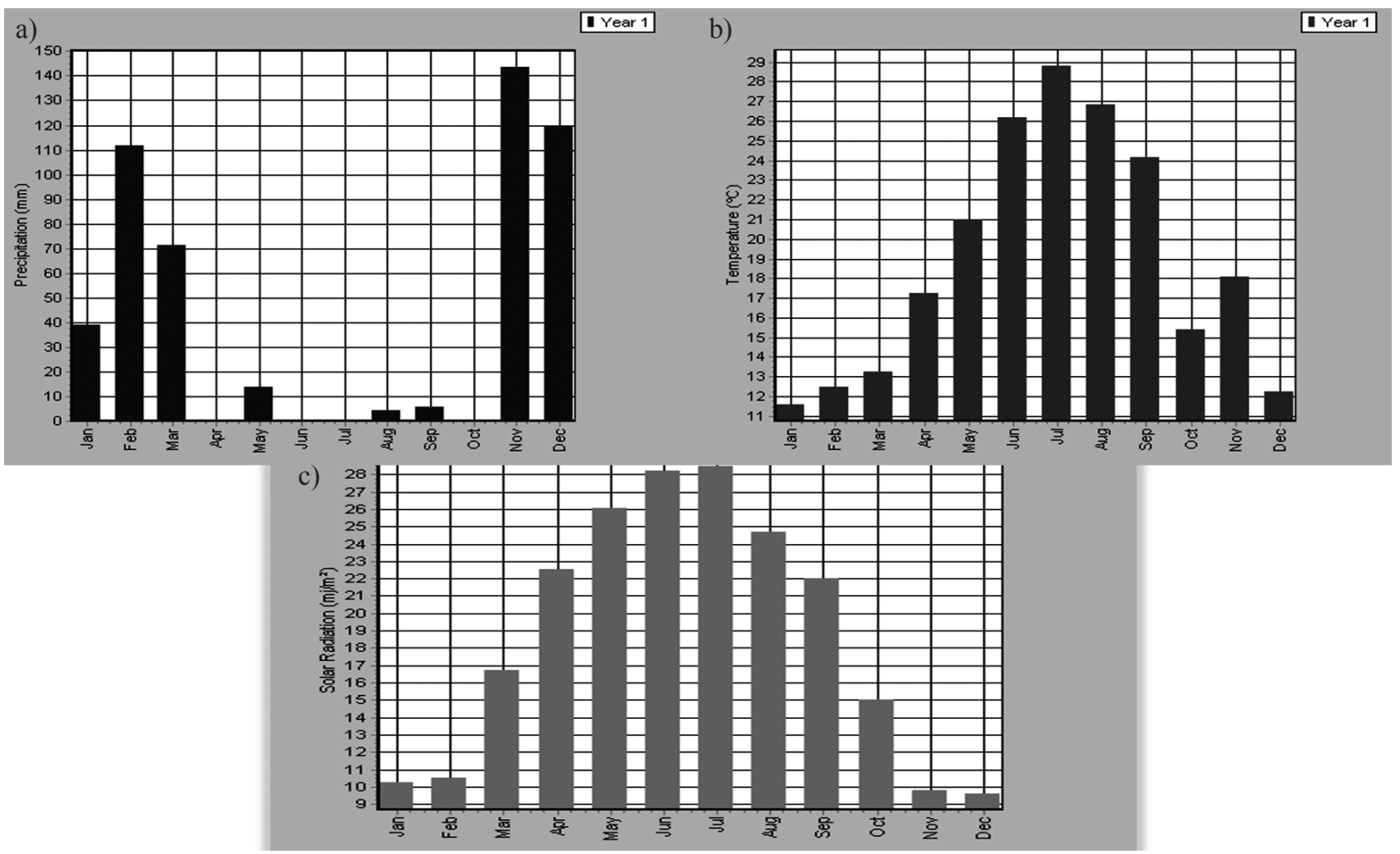

Fig. 5. Precipitation a), temperature b) and solar radiation c) values for Göksu Delta.

to groundwater. This showed us that the groundwater salinization threat exists (Fig. 6).

\section{Nitrogen Pollution in Groundwater}

The results of the minimum/maximum pollutant concentrations (temperature $(\mathrm{T})$, electrical conductivity (EC), salinity (sal), $\mathrm{pH}$, nitrite, nitrate, ammonium, and phosphate) taken from the samples in groundwater were given in Table 5. The results of the groundwater analysis (Nitrite-N, Nitrate-N, Ammonium-N, and phosphate) with the Microsoft Excel program, was transferred to the chart to compare with drinking water standards (Water Pollution Control Regulation (WPCR) [49] Class 1 water limit values and the U.S. EPA [50]) (Fig. 7).

Alkaline characteristics of groundwater were determined according to the groundwater analysis results. Alkaline property is caused by a region's geological structure. None of the results indicated exceeding $\mathrm{pH}$ limits according to the ranges of WPCR-1 ${ }^{\text {st }}$ Class Water and the U.S. EPA Drinking Water Standard (6.5 to 8.5) (Table 5). Electrical conductivity and salinity values were found to be higher in wells near the sea and Paradeniz Lake.

The wells (D17, D18, D11, D15, D16, D20, B1, B2, B5) intensely including ammonium ion compared to other wells were determined to the east and west of Göksu River (around Altinkum, Kurtuluş, and Sökün villages). When an agricultural crop pattern map (Fig. 2) was analyzed in these villages, greenhouse, strawberry, citrus, and rice farming was determined. When considering the used fertilizers and pesticide tables of Göksu Delta, the use of intensive ammonium sulfate/nitrate fertilizers in 3 periods (February, July, September) was identified. The nitrate ions are washed throughout the soil zone and so the retardation coefficient of the nitrate ion is considered very small or zero [10]. In previous research for the delta, soil properties were determined as $\mathrm{pH} 8$ (alkaline), $25 \% \mathrm{CaCO}_{3}, 2 \%$ organic matter, $30 \%$ sand, $26 \%$ clay, and $34 \%$ silt $[6,9]$. When the delta soil properties were considered, the nitrate anion will not be able to be retained in the soil. The nitrate amount filtered underground depends on the amount of applied fertilizer and its usability by plants. The growth of the plant slows down in the winter and spring months and the amount of nitrate taken by the plant decreases. Nonetheless, groundwater transition of nitrate in the soil is increasing with the effect of rainwater [10].

The wells (D2, D9, D8, D10, D15, B3, B4, B10, B14, B15, B23, B24, B27) intensely included nitrate ion compared to other wells determined at the east and west of the Göksu River (around the Altinkum, Kurtuluş, Sökün, Bahçe, Ulugöz, and Gülümpaşalı villages). Firstperiod results of nitrate ions were determined to be higher compared to the following periods. The cause of this, during the first period (February) the growth of plants in the study area decreased and nitrate ions accumulated in the soil. Thus, accumulated nitrate in the soil was assumed to move to the groundwater with rainfall and irrigation water. When the regions where 
Table 3. Major ion results of surface and groundwater analysis (mg/L).

\begin{tabular}{|c|c|c|c|c|c|c|c|c|c|c|}
\hline $\begin{array}{l}\text { Groundwater } \\
\text { Sample point }\end{array}$ & $\mathrm{X}(\mathrm{m})$ & $\mathrm{Y}(\mathrm{m})$ & $\mathrm{Na}^{+}$ & $\mathrm{K}^{+}$ & $\mathrm{Mg}^{2+}$ & $\mathrm{Ca}^{2+}$ & $\mathrm{Cl}^{-}$ & $\mathrm{SO}_{4}^{2-}$ & $\mathrm{CO}_{3}{ }^{2-}$ & $\mathrm{HCO}_{3}^{-}$ \\
\hline $\mathrm{B} 23$ & 584146 & 4023534 & 38.91 & 62.25 & 19.21 & 10.3 & 55.49 & 69.14 & 20 & 225 \\
\hline B28 & 584132 & 4020914 & 46.65 & 13.07 & 23.8 & 37.68 & 33.87 & 26.32 & 20 & 145 \\
\hline D17 & 590609 & 4025492 & 36.03 & 14.56 & 52.21 & 88.15 & 35.86 & 75.14 & 40 & 325 \\
\hline B7 & 590687 & 4023003 & 26.2 & 12.92 & 43.14 & 74.24 & 15.1 & 41.31 & 90 & 265 \\
\hline B5 & 590049 & 4021586 & 38.88 & 15.03 & 30.53 & 29.73 & 56.36 & 22.9 & 40 & 230 \\
\hline $\mathrm{B} 10$ & 590359 & 4022596 & 35.35 & 13.42 & 70.08 & 67.34 & 26.31 & 83.77 & 50 & 305 \\
\hline D21 & 592489 & 4025404 & 129.29 & 17.01 & 66.77 & 91.97 & 95.62 & 159.47 & 30 & 400 \\
\hline B17 & 588255 & 4024406 & 19.92 & 12.66 & 34.67 & 67.46 & 53.94 & 50.01 & 20 & 150 \\
\hline D6 & 590322 & 4024846 & 22.3 & 13.62 & 55.86 & 118.58 & 26.64 & 141.76 & 10 & 350 \\
\hline D23 & 592989 & 4025745 & 101.96 & 23.35 & 39.16 & 47.23 & 149.96 & 40.06 & 40 & 175 \\
\hline B25 & 583035 & 4022250 & 30.29 & 11.21 & 28.94 & 92.41 & 52.5 & 54.41 & 0 & 230 \\
\hline D15 & 594877 & 4023102 & 129.26 & 36.27 & 54.18 & 53.74 & 87.87 & 69.85 & 30 & 395 \\
\hline B11 & 589569 & 4023617 & 33.73 & 14.04 & 32.57 & 55.26 & 49.25 & 39.5 & 20 & 220 \\
\hline \multicolumn{11}{|c|}{ Surface water sample point } \\
\hline Sökün Bridge & 591453 & 4023145 & 10.58 & 12.13 & 19.19 & 64.91 & 10.89 & 33.1 & 30 & 140 \\
\hline Regulator & 582869 & 4029092 & 11.12 & 12.19 & 19.06 & 65.94 & 11 & 36.33 & 30 & 140 \\
\hline Paradeniz Lake & 588885 & 4017363 & 5457.9 & 266.59 & 517.33 & 166.08 & 9177.12 & 97.508 & 50 & 100 \\
\hline Mediterranean sea & 596865 & 4024296 & 6978.9 & 599.17 & 623.1 & 561.99 & 13921.1 & 410.147 & 50 & 70 \\
\hline Akgöl Lake & 587003 & 4016404 & 35 & 1.32 & 20.9 & 18.08 & 19.12 & 94.4 & 60 & 150 \\
\hline
\end{tabular}

nitrate ions are intensive were evaluated with the map of agricultural crop pattern, these regions were observed to make citrus production.

The wells (D24, D17, D6, D7, D1, D19, D20, B1, B3, B4, B6, B7,B8, B9) intensely including phosphate ions compared to other wells determined around the
Altınkum, Arkarası, Kurtuluş, Sökün, and Bahçe villages. First-period results of phosphate ions were determined to be lower compared to other periods. When the regions where intensive of phosphate ions were evaluated with the map of an agricultural crop pattern (Fig. 2), these regions were observed to have

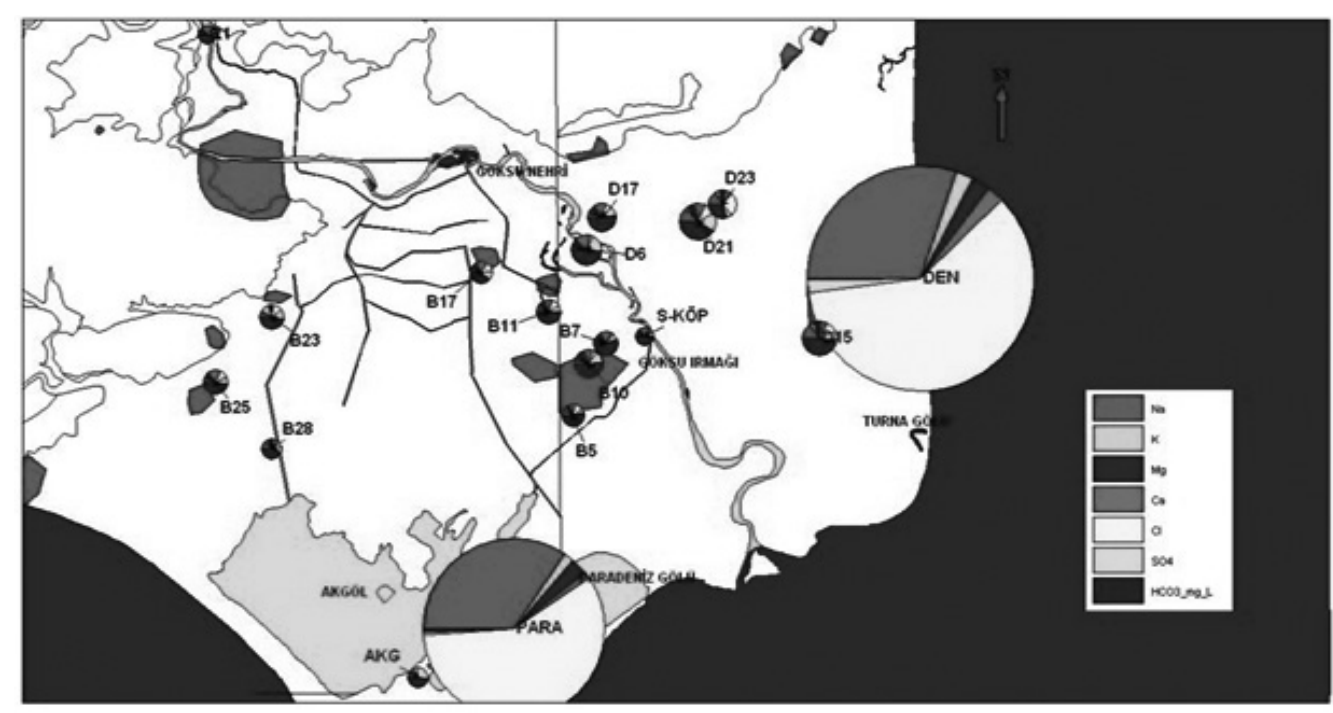

Fig. 6. Pie diagrams according to the major ion analysis of surface and groundwater. 
Table 4. Göksu Delta, surface and groundwater chemical facies (type).

\begin{tabular}{|c|c|c|c|}
\hline Groundwater ID & Chemical facies & Surface water ID & Chemical facies \\
\hline $\mathrm{B} 10$ & $\mathrm{Mg}-\mathrm{Ca}-\mathrm{HCO}_{3}$ & Akgöl Lake (Akg-1) & $\mathrm{Na}-\mathrm{HCO}_{3}-\mathrm{CO}_{3}-\mathrm{SO}_{4}$ \\
\hline B11 & $\mathrm{Ca}-\mathrm{Mg}-\mathrm{HCO}_{3}$ & Mediterranean sea & $\mathrm{Na}-\mathrm{Cl}$ \\
\hline B17 & $\mathrm{Ca}-\mathrm{Mg}-\mathrm{HCO}_{3}-\mathrm{Cl}$ & Paradeniz Lake (Para-1) & $\mathrm{Na}-\mathrm{Cl}$ \\
\hline $\mathrm{B} 23$ & $\mathrm{Na}-\mathrm{K}-\mathrm{Mg}-\mathrm{HCO}_{3}-\mathrm{Cl}-\mathrm{SO}_{4}$ & Regulator (R-1) & $\mathrm{Ca}-\mathrm{Mg}-\mathrm{HCO}_{3}$ \\
\hline B25 & $\mathrm{Ca}-\mathrm{Mg}-\mathrm{HCO}_{3}$ & Sökün Bridge (SK-1) & $\mathrm{Ca}-\mathrm{Mg}-\mathrm{HCO}_{3}-\mathrm{CO}_{3}$ \\
\hline B28 & $\mathrm{Na}-\mathrm{Mg}-\mathrm{Ca}-\mathrm{HCO}_{3}$ & & \\
\hline B5 & $\mathrm{Mg}-\mathrm{Na}-\mathrm{Ca}-\mathrm{HCO}_{3}-\mathrm{Cl}$ & & \\
\hline B7 & $\mathrm{Ca}-\mathrm{Mg}-\mathrm{HCO}_{3}-\mathrm{C}_{\mathrm{O}} 3$ & & \\
\hline D15 & $\mathrm{Na}-\mathrm{Mg}-\mathrm{Ca}-\mathrm{HCO}_{3}$ & & \\
\hline D17 & $\mathrm{Ca}-\mathrm{Mg}-\mathrm{Cl}-\mathrm{HCO}_{3}$ & & \\
\hline D21 & $\mathrm{Na}-\mathrm{Mg}-\mathrm{Ca}-\mathrm{HCO}_{3}-\mathrm{SO}_{4}$ & & \\
\hline D23 & $\mathrm{Na}-\mathrm{Mg}-\mathrm{Ca}-\mathrm{Cl}-\mathrm{HCO}_{3}$ & & \\
\hline D6 & $\mathrm{Ca}-\mathrm{Mg}-\mathrm{HCO}_{3}-\mathrm{SO}_{4}$ & & \\
\hline
\end{tabular}

citrus, strawberries, greenhouse, wheat, and rice production.

\section{Isotope Analysis Results}

The ${ }^{15} \mathrm{~N}$ isotope results of fertilizer (ammoniumnitrate) and wastewater were determined in line with the literature isotope rates $[38,51,52]$. Comparing ${ }^{15} \mathrm{~N}$ isotope results of fertilizer (ammonium-nitrate) and the wastewater with the results of groundwater pollution sources of nitrogen in the Göksu Delta were determined. The high difference between the fertilizer and wastewater isotopic values was facilitated by the nitrogen source (Table 6). The isotope analysis results are given in Table 6. The $\delta^{15} \mathrm{~N}$ isotope values increased in the samples taken during the wet season ( $1^{\text {st }}$ period) more than dry season $\left(2^{\text {nd }}\right.$ period $)$. Nitrate ions were considered to be filtered through the soil to underground with rain and irrigation water in the wet season (Fig. 8). According to the isotope analysis, in the wet season, the source of nitrogen pollution of B5-B10-B11 wells (around Kurtuluş-Sökün villages) were identified as wastewater. The source of nitrogen pollution of D15 was identified as fertilizer and wastewater (Fig. 8). According to the isotope analysis, in the dry season, the sources of nitrogen pollution of D15-B11 wells were identified as wastewater and fertilizer. The sources of nitrogen pollution of B10-B5 wells were identified as fertilizer and soil nitrogen (Fig. 9). The $\delta^{15} \mathrm{~N}$ values could not identify the nitrogen pollution source in the samples taken on Göksu River because there was not enough nitrogen data for source identification (Figs 8-9).

Table 5. Shown minimum/maximum $\mathrm{pH}$, temperature, electrical conductivity, salinity, ammonium-N, nitrite-N, phosphate values of wells each period.

\begin{tabular}{|c|c|c|c|c|c|c|}
\hline \multirow[b]{2}{*}{ Parameters } & \multicolumn{2}{|c|}{ 1.Period } & \multicolumn{2}{|c|}{ 2.Period } & \multicolumn{2}{|c|}{ 3.Period } \\
\hline & Min. & Max. & Min. & Max. & Min. & Max. \\
\hline $\mathrm{pH}$ & 7.04 & 8.47 & 7.16 & 8.47 & 7.10 & 8.34 \\
\hline Temperature $\left({ }^{\circ} \mathrm{C}\right)$ & 15.1 & 21.7 & 21.10 & 29.8 & 16.3 & 21.7 \\
\hline Electrical Conductivity $(\mu \mathrm{S} / \mathrm{cm})$ & 459 & 5240 & 483 & 5830 & 451 & 5600 \\
\hline Salinity (sal) & 0.00 & 2.8 & 0.00 & 3.2 & 0.00 & 3.0 \\
\hline Ammonium-N (mg/L) & 0.00 & 10.4 & 0.00 & 5.29 & 0.00 & 3.2 \\
\hline Nitrite-N (mg/L) & 0.00 & 0.04 & 0.00 & 0.04 & 0.00 & 0.03 \\
\hline Nitrate-N (mg/L) & 0.00 & 27.0 & 0.00 & 19.8 & 0.00 & 16.10 \\
\hline $\begin{array}{c}\text { Phosphate } \\
\text { (mg/L) }\end{array}$ & 0.00 & 2.48 & 0.00 & 6.4 & 0.00 & 5.9 \\
\hline
\end{tabular}



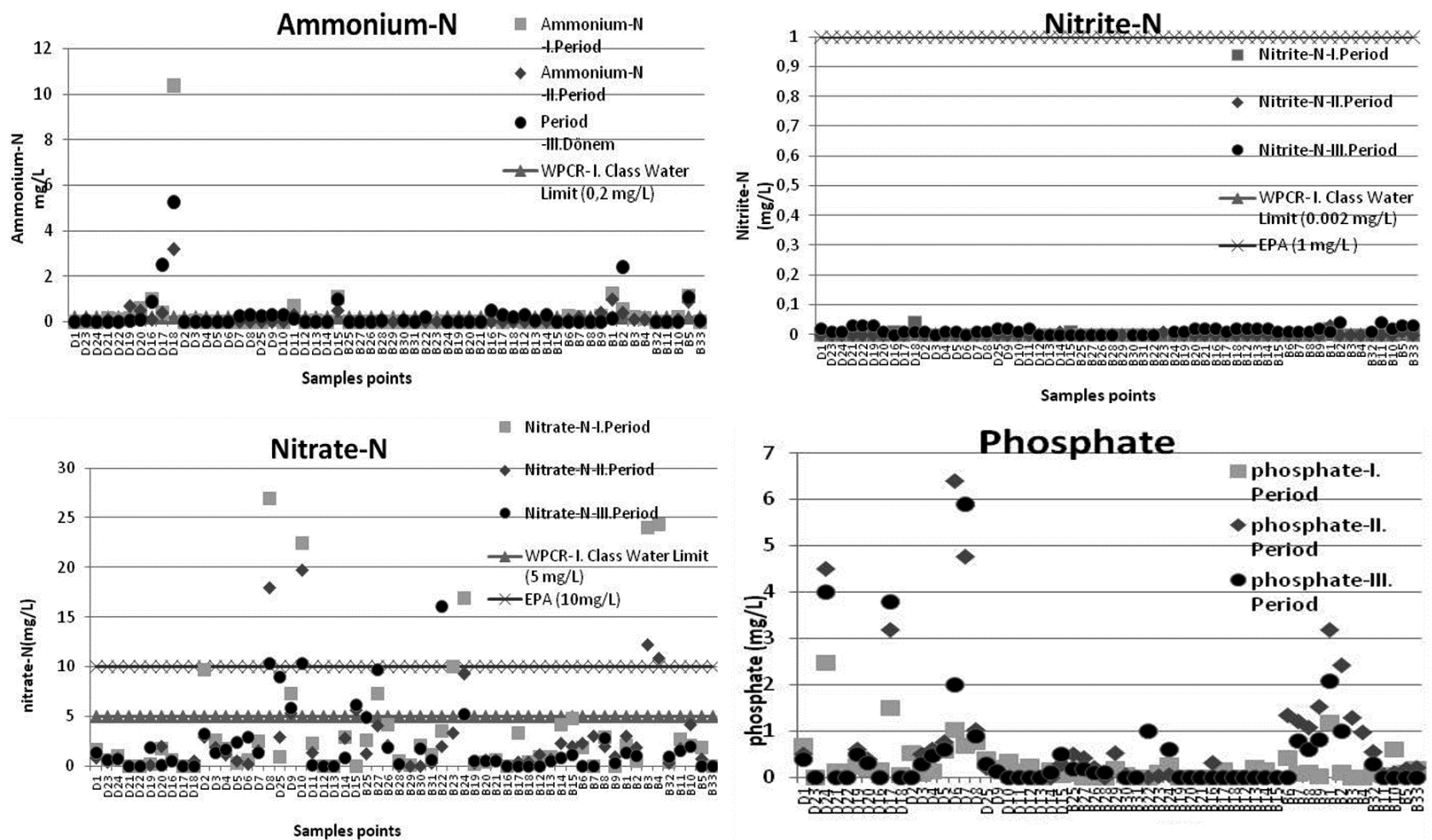

Fig. 7. Charts of groundwater analysis (Nitrite-N, Nitrate-N, Ammonium-N, Phosphate).

Göksu Delta Groundwater Flow and Pollution Model Results

\section{Groundwater Flow Model}

Groundwater flow and the sources of pollution at the field site were calculated using MODFLOW, a U.S. Geological Survey block-centered finite-difference computer code that solves the groundwater flow equation [53, 54]. We used the Visual MODFLOW pre- and post-processors (Waterloo Hydrogeologic, Inc.) and the model was run in steady state. Boundary conditions to generate flow model were defined as follows; Mediterranean coastline, Akgöl Paradeniz Constant Head $(\mathrm{CH})$; other areas were determined as no-flow. No-flow passive cells were not taken into account in any way in the calculations. General Head Boundary (GHB) conditions were determined for cells located in the border of between active cells and passive cells. Cells, except the feeding basin boundary, were defined

Table 6. Wet/Dry season (periods 1-2) isotope analysis results.

\begin{tabular}{|c|c|c|c|c|c|c|c|}
\hline $\begin{array}{c}\text { Sample point } \\
\text { (wet season) }\end{array}$ & $\begin{array}{c}\delta^{18} \mathrm{O}_{\text {V-SMOw }} \\
(\%)\end{array}$ & $\begin{array}{c}\delta^{2} \mathrm{H}_{\text {V-SMOw }} \\
(\%)\end{array}$ & $\delta^{15} \mathrm{~N}_{\text {air(\%) }}$ & $\begin{array}{c}\text { Sample point } \\
(\text { dry season) }\end{array}$ & $\begin{array}{c}\delta^{18} \mathrm{O}_{\text {V-SMOw }} \\
(\% 0)\end{array}$ & $\begin{array}{c}\delta^{2} \mathrm{H}_{\text {V-SMOw }} \\
(\%)\end{array}$ & $\delta^{15} \mathrm{~N}_{\text {air(\%o) }}$ \\
\hline Sökün river & -9.05 & -56.86 & 20.57 & Sökün river & 0.8 & -58.21 & 3.17 \\
\hline $\begin{array}{c}\text { Regulator (on Göksu } \\
\text { River) }\end{array}$ & -9.35 & -57.33 & 28.33 & $\begin{array}{c}\text { Regulator (on Göksu } \\
\text { River) }\end{array}$ & 1.34 & -56.82 & 3.95 \\
\hline Mediterranean Sea & 1.41 & 15.34 & - & Mediterranean Sea & 1.35 & 13.69 & - \\
\hline B10 (well) & -8.4 & -50.52 & 54.11 & B10 (well) & -8.12 & -50.85 & 3.86 \\
\hline D15 (well) & -8.22 & -50.09 & 19.63 & D15 (well) & -8.15 & -52.52 & 29.44 \\
\hline B5 (well) & -8.99 & -54.55 & 58.07 & B5 (well) & -8.99 & -56.36 & 4.13 \\
\hline B11 (well) & -8.69 & -53.18 & 38.18 & B11 (well) & -8.6 & -53.98 & 10.25 \\
\hline Waste water (domestic) & -7.38 & -44 & 44.52 & & & & \\
\hline $\begin{array}{c}\text { Fertilizer } \\
\text { (Ammonia-nitrate) }\end{array}$ & -8.31 & -46.8 & 2.33 & & & & \\
\hline
\end{tabular}

$*_{-}$: under detection limit 


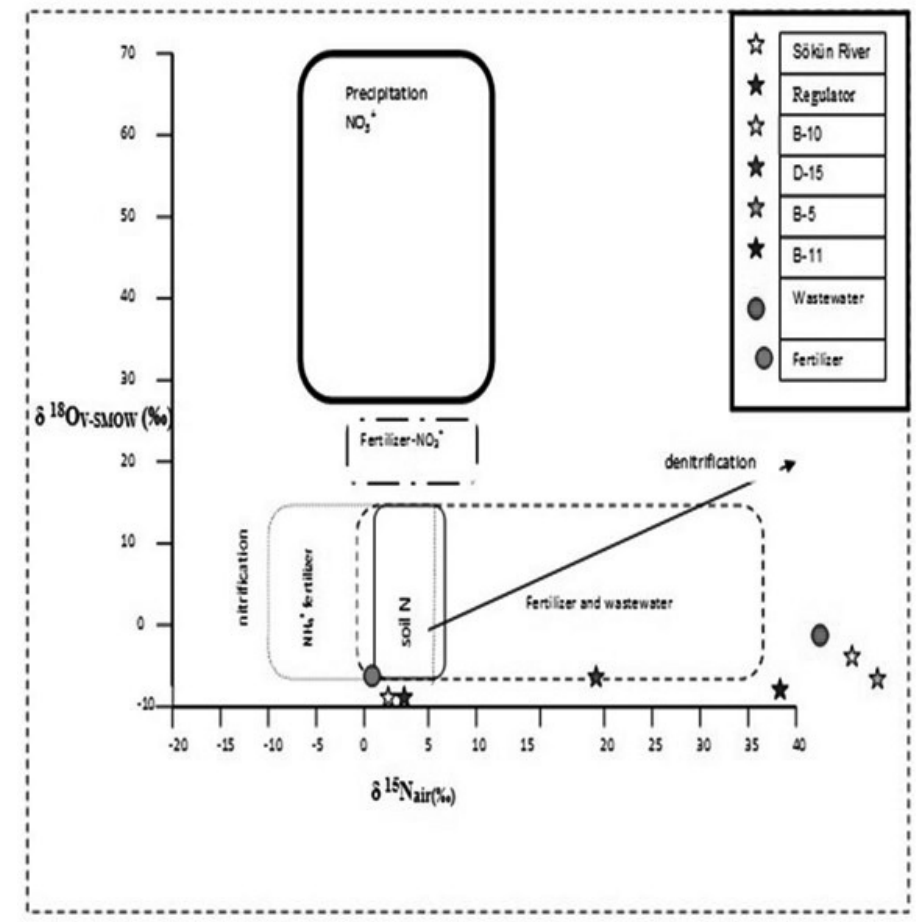

Fig. 8. Results of isotopic composition of $\delta{ }^{18} \mathrm{O}_{\mathrm{v}-\mathrm{Smow}}(\%)$ and $\delta{ }^{15} \mathrm{~N}_{\text {air(\%) }}$ in nitrate in water samples taken from the groundwater and surface water for wet season (boxes show typical ranges of $\delta^{18} \mathrm{O}$ and $\delta^{15} \mathrm{~N}$ in nitrate from various source $[28,37]$ ).

as the inactive cells. These cells did not participate in the groundwater flow equation. Initial water level values of Akgöl Lake, Paradeniz Lake, and the Mediterranean were taken as $0.6 \mathrm{~m}, 0497 \mathrm{~m}$, and $0 \mathrm{~m}$, respectively [7]. This study includes an area of $155 \mathrm{~km}^{2}$, with an $\mathrm{x}$-direction of $10 \mathrm{~km}$ and a y-direction of $15 \mathrm{~km}$, in the ED50/UTM zone 36S. All data were entered using UTM coordinates. The aquifer of the study area was modeled by finite difference method. A rectangulardimensional model network was created for the study

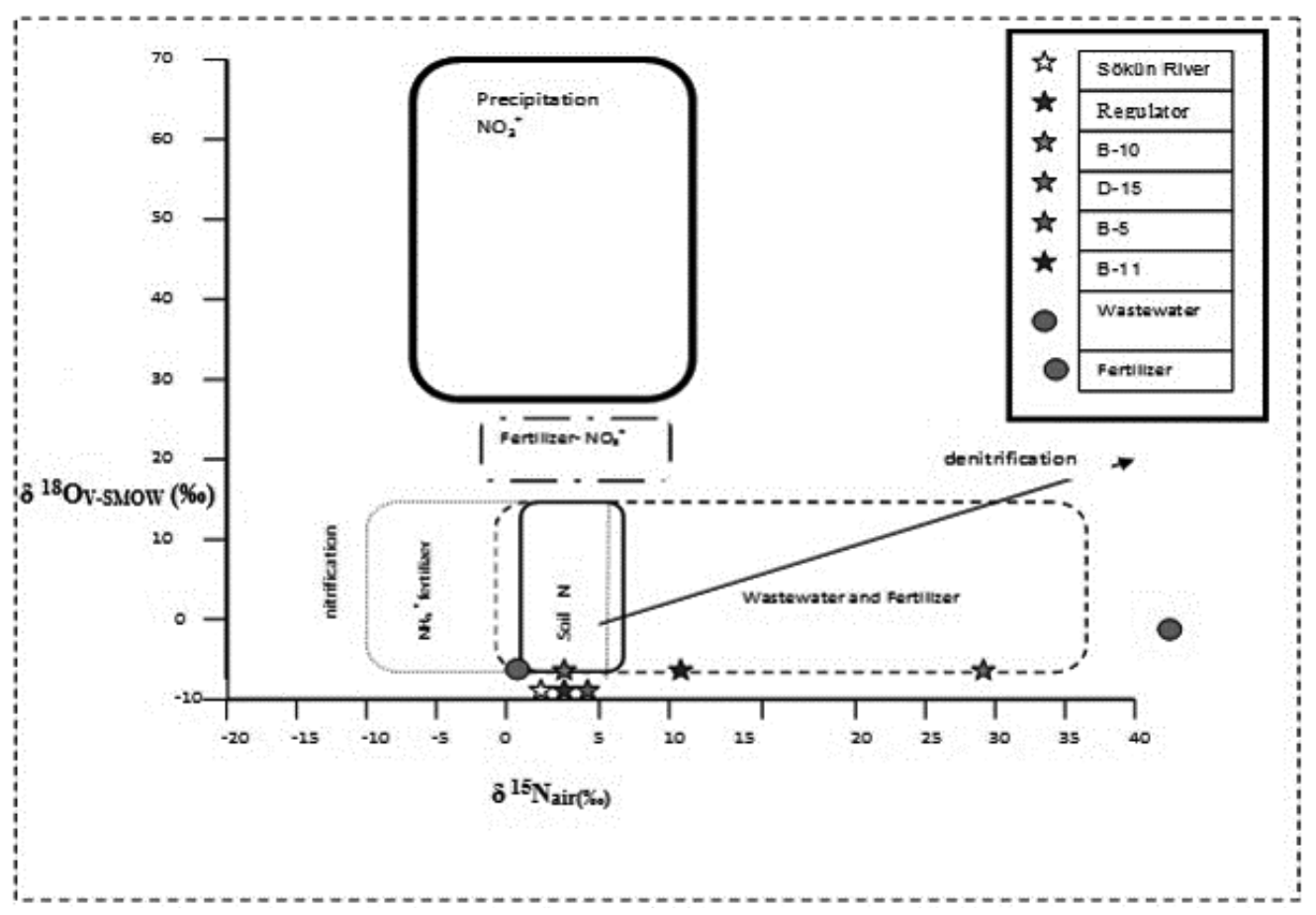

Fig. 9. Results of isotopic composition of $\delta{ }^{18} \mathrm{O}_{\mathrm{V}-\mathrm{SmOw}}(\%)$ and $\delta{ }^{15} \mathrm{~N}_{\text {air(\%) }}$ in nitrate in water samples taken from the groundwater and surface water for dry season. (Boxes show typical ranges of $\delta^{18} \mathrm{O}$ and $\delta^{15} \mathrm{~N}$ in nitrate from various source [28,37]. 
area. This is a rectangular-dimensional model network consisting of 75,000 cells, 150 rows, and 100 columns (200 $\mathrm{m}$ thick) (Fig. 10a). The thickness of the aquifer was accepted as $200 \mathrm{~m}$ (considering previous studies) and the aquifer was modeled as a five-layer one. The thickness of the layer was different and regarded as $5 \mathrm{~m}, 5 \mathrm{~m}, 40 \mathrm{~m}, 50 \mathrm{~m}$, and $100 \mathrm{~m}$, respectively. More than 100 elevation values of aquifer were imported to the Visual MODFLOW. Unknown elevation values were produced using the Kriging interpolation method by the Visual MODFLOW model. In the delta, the feeding of groundwater is mainly by infiltration of precipitation and river waters. Discharge from the aquifer system is occurred by water outlet to Göksu River, lakes, and sea, with water drawn from wells. The necessary data for modeling was conducted using previous studies' data in the study area. Storage coefficient was accepted as $0.01 \mathrm{~m}^{-1}$ for $1^{\text {st }}, 2^{\text {nd }}$, and $3^{\text {rd }}$ layers $, 0,001 \mathrm{~m}^{-1}$ for the $4^{\text {th }}$ layer, and $0.0001 \mathrm{~m}^{-1}$ for $5^{\text {th }}$ layer. Horizontal and vertical hydraulic conductivity values were adopted for the study area as $x-y$ direction 110-140 m/day and $\mathrm{z}$ direction $0.04-0.001 \mathrm{~m} /$ day [7]. For the study area,
$100 \mathrm{~m}$ longitudinal dispersivity value and $10 \mathrm{~m}$ transverse dispersivity value were accepted [55].

Rains are an important resource for groundwater. In the rainy season, groundwater levels are observed to rise. Groundwater recharge data for the study area was used to get the VHELP modeling results. According to the results of VHELP, the average annual amount of groundwater recharge is $72.72 \mathrm{~mm}(0.00019 \mathrm{~m} /$ day $)$. In addition to recharge of the rainwater, recharge sourced from irrigation was accepted to the east of Göksu River as $0.00065 \mathrm{~m} /$ day and west of the river as $0.00061 \mathrm{~m} /$ day [7] (Fig. 10b).

\section{Groundwater Nitrate Transport Modeling}

Firstly, groundwater flow model of the study area was created using the Visual MODFLOW and then the transport of nitrate was modeled. Coordinates, depth, pumping, and nitrate concentration data of the 48 pumping wells were transferred to the Visual MODFLOW model for the nitrate transport model. Estimated values of the unknown points were
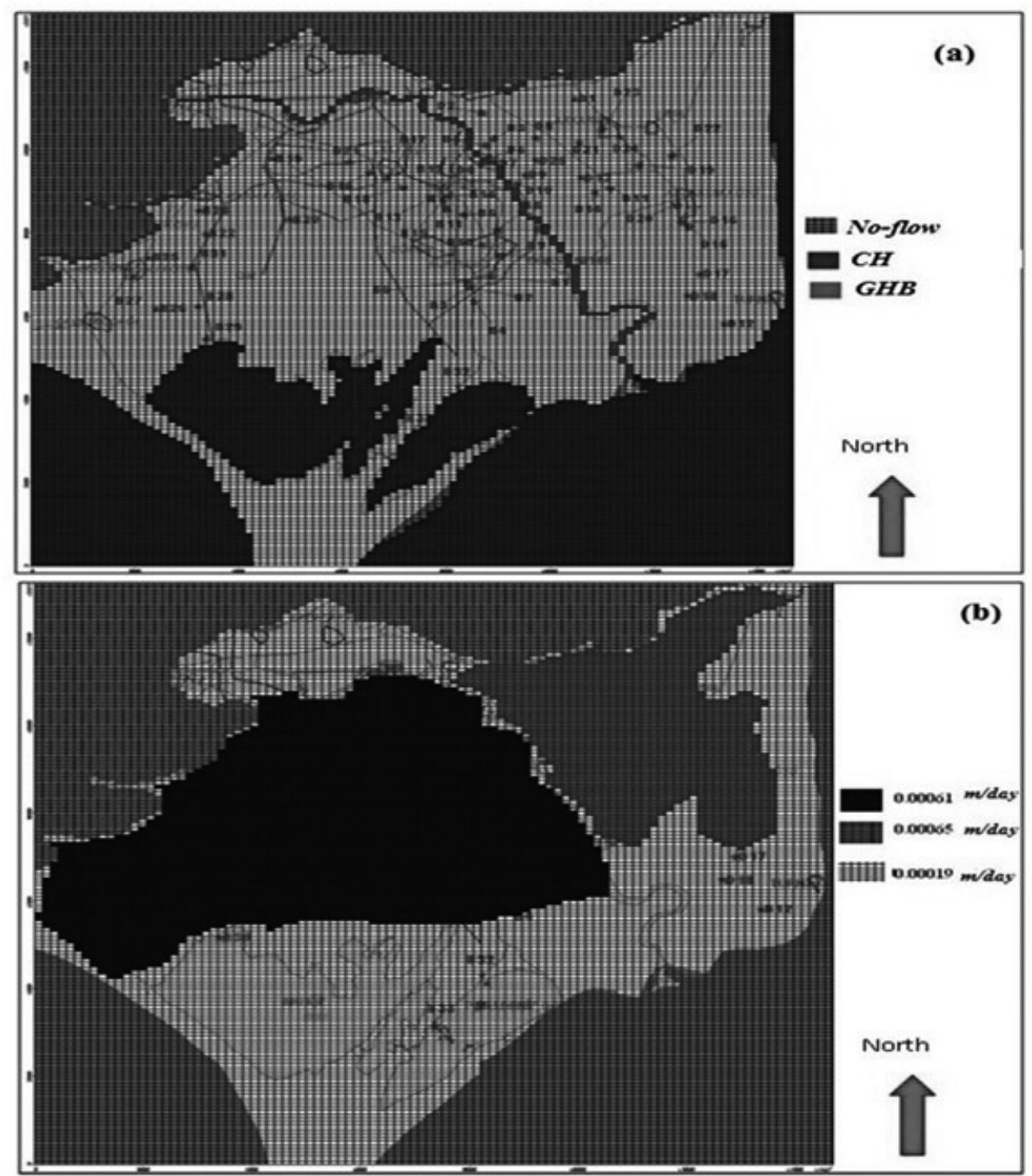

Fig. 10. Göksu Delta finite difference model network a), Göksu Delta groundwater recharge distribution map b). 
provided using the Kriging interpolation method by Visual MODFLOW. For nitrate transport model an MT3DMS package was used that exists within the Visual MODFLOW. MT3DMS can be used to simulate changes in concentrations of miscible contaminants in groundwater considering advection, dispersion, diffusion, and some basic chemical reactions with various types of boundary conditions and external sources or sinks. MODPATH tracks the trajectory of a set of particles from user-defined starting locations using the MODFLOW solution as the flow field. The particles can be tracked either forward or backward in time. In this study, after establishing groundwater fate and transport model (MT3DMS), we have investigated nitrate pollution source by the particle tracking analyses (MODPATH).

Model calibration is based on the comparison of observed groundwater levels to the calculated groundwater levels in cells by the model. Generally, horizontal and vertical hydraulic conductivity values are used as calibration parameters for calculating the change of water levels between observed water levels and calculated water levels [56]. Calculated head with observed head in wells showed a fairly good correlation (Fig. 11a). This situation proved us the correctness of the study area model. Calibration of the nitrate transport model results were shown to be acceptable for the transport model (Fig. 11b). As a result of the Visual MODFLOW flow model, the Göksu delta groundwater flow direction is north to south/southeast to the Mediterranean Sea (Fig. 12a). Mainly, contaminants are transported by advection and hydrodynamic dispersion in groundwater systems. The groundwater flow path must be known for the transport of the contaminant. In this study, nitrate flow path was estimated using the Visual ModflowPATH (MODPATH) module. In the intensive farming regions of the delta, possible sources of nitrate pollution (5 years ago) were identified with the particle tracking method (Fig. 12b). A map of nitrate pollution showed that nitrate ions were moving into the delta as parallel to groundwater flow from the settlement areas (Fig. 12b). In Fig. 12b), another source of nitrate pollution in the delta was found as the settlements. When model isotope results were evaluated we found that nitrate ions were found almost everywhere in the delta, but that maximum values were reached in nitrate concentration in settlements near the sea. The nitrate ions were carried from north to south/south direction, in the direction of the flow of the groundwater, and it reaches the maximum concentration in these regions by accumulating. The nitrogen-15 isotope results supported the model results, and domestic wastewater in Göksu Delta was determined as the main source of nitrate pollution. The agricultural product map (Fig. 2) created for the delta demonstrated that agricultural activities started from the bottom part of Silifke city. According to the results of the groundwater contaminant transport model, 5 years ago nitrate pollution was found to have started from Silifke city and the surrounding settlement. a)

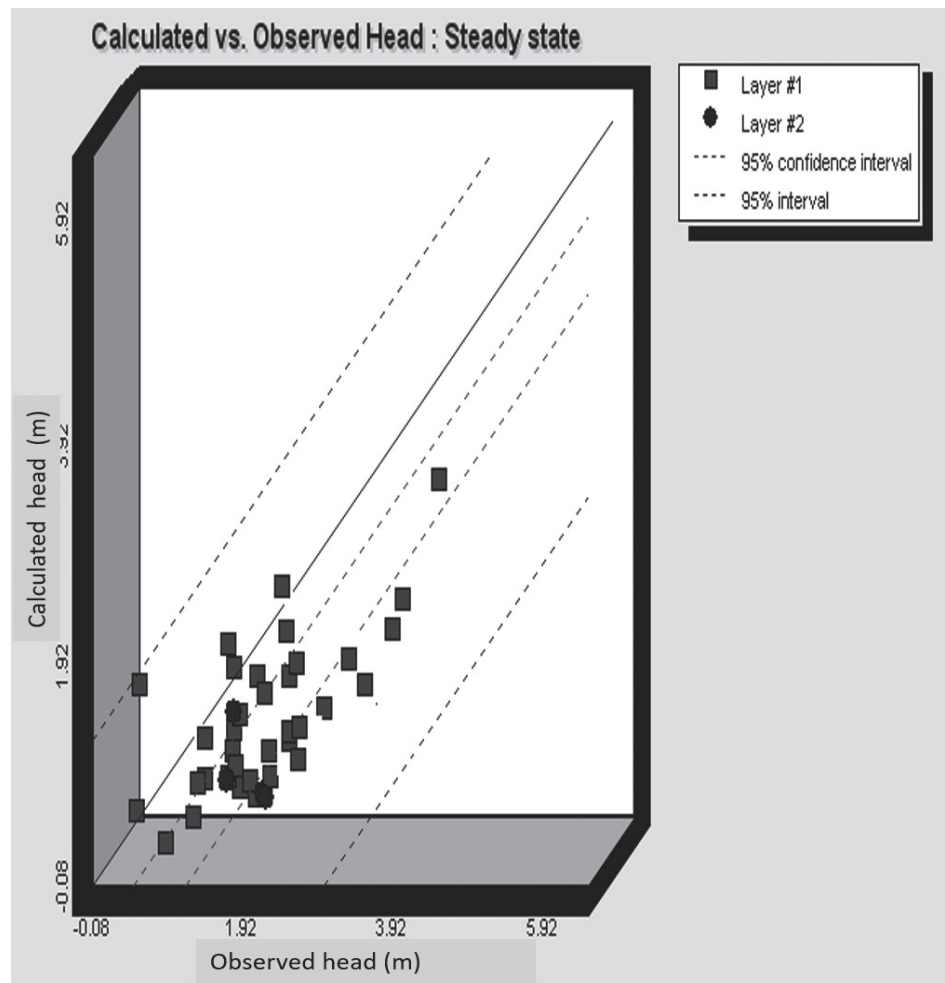

b)

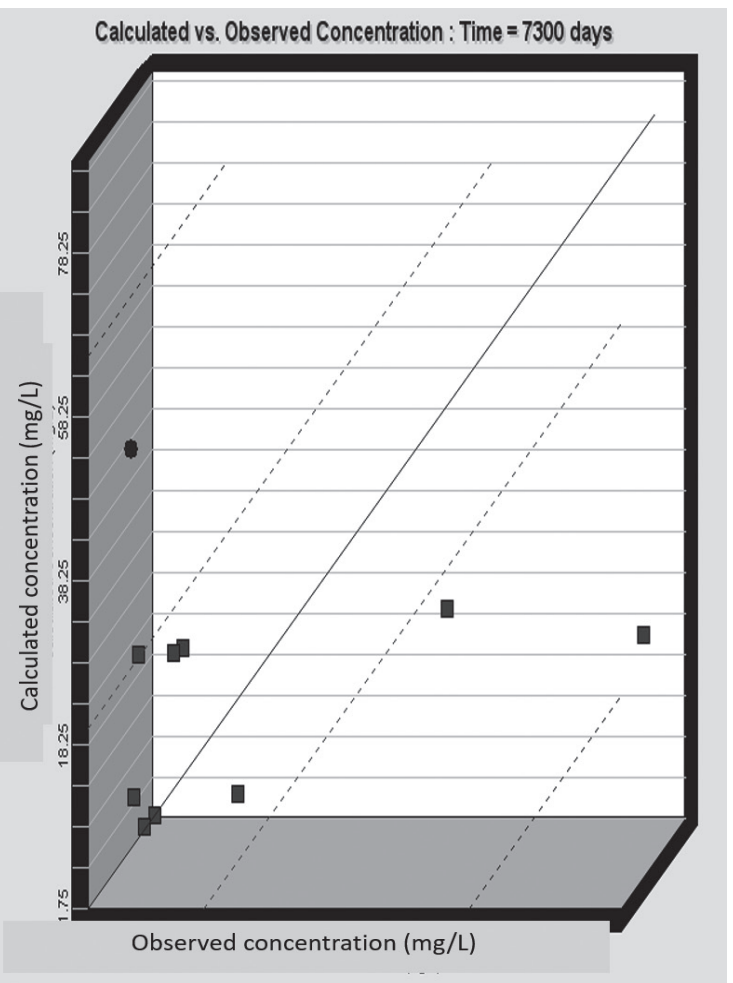

Fig. 11. a) model, hydraulic head calibration results b) calibration results of nitrate concentration. 


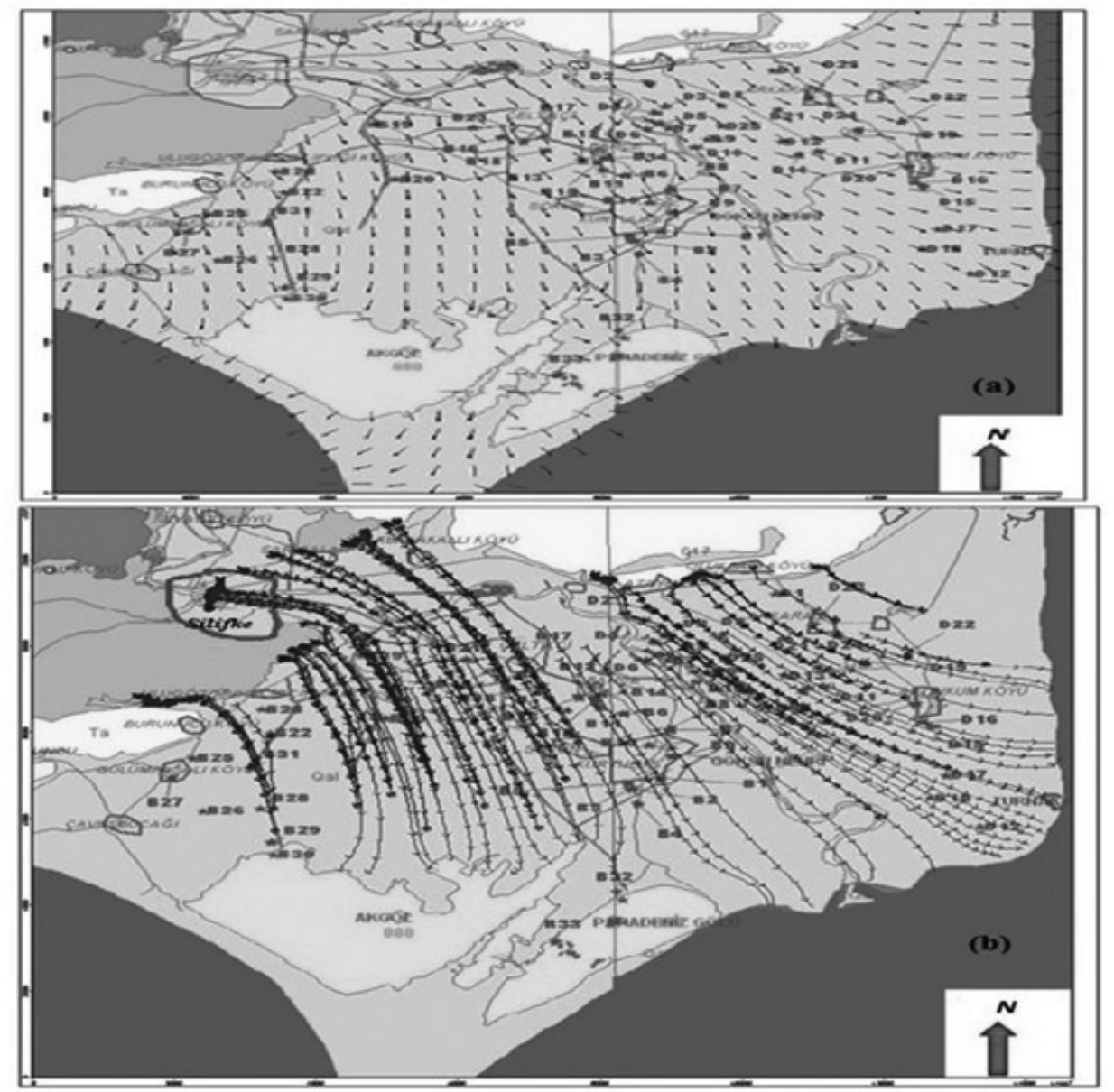

Fig. 12. Göksu Delta, groundwater flow velocity vectors a), Results of simulating nitrate transport routes in Göksu Delta 5 years ago (by the MODPATH) b).

\section{Conclusions}

In this study we determined the main source of nitrogen pollution in the world-famous Göksu Delta wetland, using two main methods: the stable isotope technique and groundwater modeling. These two methods were combined and the results were evaluated. Previously, this combined method was not used to determine the source of nitrogen pollution in the literature. In the study area, the results depending on time and spatial distribution of pollution were examined to make a comparison together with the agricultural pattern map. The agricultural pattern map was used to assess the effect of agricultural activities on nitrogen compounds in the groundwater. Citrus and strawberry production is common in the studied area. The distribution of used chemical fertilizers and pesticides in these products according to the month is also determined with this study. With this data in this part of the study, the change of nitrogen pollution depending on the time and spatial in the delta was determined.

In recent decades, the hydrology of the delta has been transformed by agricultural development. While Table 1 gives information about used fertilizers and pesticides, it cannot help with sourced pollution from wastewater in Göksu Delta groundwater. The source of nitrogen pollution in groundwater was determined by nitrogen isotope analysis.

Recharging groundwater in the study area is mainly sourced from precipitation and irrigation waters. Groundwater recharge was calculated using meteorological data from the VisualHELP model. Types of groundwater are determined by major ion analysis. The predominant ion was bicarbonate in groundwater. The chloride ion was observed in almost each well. This showed us that the threat of groundwater salinization is existent. Nitrogen and phosphate concentrations in the groundwater were monitored depending on the time and the agricultural crop pattern of Göksu Delta. Due to the washing of nitrate accumulated in the soil with rainwater, first-period (wet seasons) results of nitrate ions were determined to be higher compared to other periods. When the regions with intensive nitrate ions were evaluated with the map of agricultural crop pattern, these regions were observed to make citrus production.

Chemical fertilizers used in agricultural production in Göksu Delta have an important role in the nitrogen contamination of the waters in this region. In the Göksu Delta septic tanks instead of sewage network exists 
and this caused the increase of nitrogen and phosphate concentrations in groundwater. The alluvial aquifer located predominantly in the study area is classified as the high sensitivity aquifer group to nitrogen contamination. Soils are known to have a net negative charge, which is the basis for cation exchange and it is normally assumed that anions such as nitrate are not adsorbed by soil particles. According to isotope analysis, for most of the wells the source of nitrogen pollution was identified as wastewater in the wet season (Fig. 8), and wastewater and fertilizer in the dry season (Fig. 9). With the samples that were taken from Göksu River, the $\delta^{15} \mathrm{~N}$ isotope values could not identify the nitrogen pollution source.

The nitrogen isotope values between wastewater and chemical fertilizer have a high difference (Table 6). This situation has been decisive in identifying nitrate sources. The results of $\delta^{15} \mathrm{~N}$ showed that nitrate in the Göksu Delta groundwater were greatly affected by agricultural activities, but mainly derived from domestic wastewater. By the particle tracking model, 5 years ago it was determined that nitrate ions come from Silifke (which does not have a wastewater treatment plant) and from surrounding settlements. When evaluated for the results of isotope and nitrogen (nitrite, nitrate, and ammonium) analysis, the nitrate ions were encountered at each point of the delta. In the settlements that are near the Mediterranean Sea, the maximum nitrate concentration has been detected.

Göksu Delta is an important wetland where the Göksu River reaches the sea in the eastern part of the Mersin, Turkey. The delta is classified as a Wetland of International Importance according to the Ramsar Convention. The delta hosts a variety of endemic and rare species that are on the verge of extinction globally. Furthermore, the most typical examples of wetlandhuman interaction are observed within the borders of the delta. In this study it has been demonstrated that groundwater quality is affected by domestic wastewater and unconsciously used chemical fertilizer.

As this study determined the wastewater as the main source of nitrogen pollution in the Göksu Delta groundwater, it needs to be collected by the sewage network. In addition, groundwater quality should be examined microbiologically, and vegetables and fruits grown with underground waters should be checked. The people living in the area should claim their stakes in these natural resources and develop their sustainable production methods. In the Göksu Delta, people working here also must be educated about the use of fertilizer according to the season and the crop.

\section{Acknowledgements}

This study is a part of the Ph.D. thesis "Modelling and Determination of Groundwater Pollution and an Investigation of Pollutant Sources Using Isotope Methods, Establishing Geographic Information Systems in Göksu Delta," which is supported by the Academic Research Projects Unit, Institute of Basic and Applied Sciences, University of Mersin (ÇM (AB) 2010-5 DR).

\section{Conflict of Interest}

The authors declare no conflict of interest.

\section{References}

1. BHANDARI M.P. The role of international organization in addressing the climate change issues and creation of intergovernmental panel on climate change (IPCC). Adv Agr Environ Sci. 1 (1), 19, 2018.

2. MIAO G., NOORMETS A., DOMEC J., TRETTIN C.C., SUN G., MCNULTY S.G., Implications in partitioning ecosystem respiration in a coastal plain forested wetland. Agr Forest Meteorol. 247, 343, 2017.

3. RAMSAR CONVENTION SECRETARIAT. Ramsar Handbooks For The Wise Use Of Wetlands $4^{\text {th }}$ Edition, Vol. 11, Gland Switzerland 2010.

4. MA Z., YANG Y., LIAN X., JIANG Y., XI B., PENG X., YAN K. Identification of nitrate sources in groundwater using a stable isotope and 3deem in a landfill in Northeast China. Sci Total Environ. 563-564, 593, 2016.

5. PAPATHEODOROU K., EVANGELIDIS K., NTOUROS K. Geomatics for environmental protection and resource management. J Environ Prot Ecol 18, 168, 2017.

6. DEMIREL Z., ÖZER O., DABANLI S. Göksu Deltası'nın Tarım, Hayvancılık, Arazi Kullanı İle İlgili 3 Boyutlu Haritalarının ve CBS'nin Oluşturulması (Creation of GIS and 3D Maps Relating to Land Use, Agriculture, Livestock in Göksu Delta), Bibad, 3 (2), , 2010.

7. COBANER M., YURTAL R., DOGAN A., MOTZ L. H.. Three dimensional simulation of seawater intrusion in coastal aquifers: A case study in the Goksu Deltaic Plain. J Hydrol. 464-465, 262, 2012.

8. DEMIREL Z., ÖZER O., ÖZPINAR Z. Investigation of groundwater pollution in a protected area in Turkey The Göksu Delta. GUJS. 24, 17, 2011.

9. SEPA-Special Environmental Protection Agency. Göksu Delta Management Plan. Ankara, Turkey, 2009.

10. KAÇAR B., KATKAT V. Gübreler ve gübreleme tekniği (fertilizers and fertilization techniques). Ankara, Turkey. Nobel Publication, 2014.

11. LINDENBAUM J . Identification of sources of ammonium in groundwater using stable nitrogen and boron isotopes in Nam Du, Hanoi. Master's thesis. Lund University. Swedish, 2012.

12. FOLLETT R.F. Nitrogen management and ground water protection. Developments in Agricultural and ManagedForest Ecology. Elsevier, 2012.

13. BALAKRISHNAN P., SALEEM A., MALLIKARJUN N.D. Groundwater quality mapping using geographic information system (GIS): A case study of Gulbarga City, Karnataka, India. Afr. J. Environ. Sci. Technol. 5 (12), 1069, 2011.

14. DIDAR-UL ISLAM S.M., BHUIYAN M.A.H., RUME T., AZAM G. Hydrogeochemical investigation of groundwater in shallow coastal aquifer of Khulna District, Bangladesh. Appl Water Sci. 7, 4219, 2017. 
15. KHOSHRAVESHA M., SEFIDKOUHIA M. A.G., ABBASPALANGIB J., MIRNASERIC M. Estimation of nitrate concentrations in well and spring water using ANFIS and SVM models (Case study: Golestan province). Journal of Applied Hydrology. 2 (2), $1,2015$.

16. PIRAJNO F. Hydrothermal mineral deposits: principles and fundamental concepts for the exploration geologist. Springer Science \& Business Media, 2012.

17. MEYERS L.M.A., NAHLIK M., DEKEYSER E.S. Relationship between the natural abundance of soil nitrogen 1sotope sand condition in North Dakota Wetlands. Ecol Indic 60, 394, 2016.

18. VIANA I.G., BODE A. Stable nitrogen isotopes in coastal macroalgae: Geographic and anthropogenic variability. Sci Total Environ. 443, 887, 2013.

19. WONG C.W.M., DUPREY N.N., BAKER D.M. New insights on the nitrogen footprint of a coastal megalopolis from coral-hosted symbiodinium $\delta^{15} \mathrm{~N}$. Environ. Sci. Technol. 51, 1981, 2017.

20. DEEK A., EMEIS K., STRUCK U..Seasonal variations in nitrate isotope composition of three rivers draining into the North Sea. Biogeosciences Discuss., 7, 6051, 2010.

21. WELDRICK C.K., JELINSKI D.E. Seasonal dynamics in a nearshore isotopic niche and spatial subsidies from multi-trophic aquaculture. Can J Fish Aquat Sci. 74 (9), 1411, 2017.

22. IZQUIERDO-GOMEZ D., SANCHEZ-JEREZ P., BAYLE-SEMPERE J.T., LOADER N.J., GARCIA DE LEANIZ C. Effects of coastal fish farms on body size and isotope composition of wild penaeid prawn. Fish Res. 172, $50,2015$.

23. FERTIG B., CARRUTHERS T.J.B., DENNISON W.C. Oyster $\delta^{15} \mathrm{~N}$ as a bioindicator of potential wastewater and poultry farming impacts and degraded water quality in a subestuary of Chesapeake Bay. J COASTAL RES. 30 (5), 881. 2014.

24. LASSAUQUE J., LEPOINT G., THIBAUT T., FRANCOUR P., MEINESZ A. Tracing sewageand natural freshwater input in a Northwest Mediterranean Bay: evidence obtained from isotopic ratios in marine organisms. Mar. Pollut. Bull. 60, 843, 2010.

25. XU L., ZHANG M. Primary consumers as bio indicator of nutrient pollution in lake planktonic and benthic feed webs. Ecol Indic 14, 189, 2012.

26. ROZIC P.Z., DOLENEC T., LOJEN S., KNIEWALD G., DOLENEC M. Using stable nitrogen isotopes in patella sp. to trace sewage-derived material in coastal ecosystems, Ecol Indic 36, 224, 2014.

27. CZEKAJ J., JAKOBCZYK-KARPIERZ S., RUBIN H., SITEK S., WITKOWSKI A.J. Identification of nitrate sources in groundwater and potential impact on drinking water reservoir (Goczałkowice Reservoir, Poland). Phys Chem Earth. 94, 3, 2016.

28. KENDALL C. Tracing nitrogen sources and cycling in catchments. In: Kendall, C., McDonnell, J.J. (Eds.), Isotope Tracers in Catchment Hydrology. Elsevier Science B.V., Amsterdam. 1998

29. BELLAMY A.R. Sources and ages of carbon and organic matter supporting macroinvertebrate production in temperate streams. $\mathrm{PhD}$ Thesis, Ohio State University, Graduate Program in Evolution, Ecology and Organismal Biology, 280, 2017.

30. LAL R., STEWART B.A. Soil nitrogen uses and environmental impact. CRC Press, 380, 2018.
31. TAMŠE S., MOZETIČ P., FRANCÉ J., OGRINC N. Stable isotopes as a tool for nitrogen source identification and cycling in the Gulf of Trieste (Northernadriatic).Cont Shelf Res 91, 145, 2014.

32. ENGEL M.H., MACKO S.A. Organic Geochemistry: Principles and Applications. Springer Science \& Business Media, 861, 2013.

33. WALLACE J. Water-quality assessment of the principal valley-fill aquifers in the southern sanpete and central sevier valleys, sanpete county, Utah. Utah Geological Survey, 138, 2010.

34. XUE Y., SONG J., ZHANG Y., KONG F., WEN M., ZHANG G. Nitrate pollution and preliminary source identification of surface water in a semi-arid river basin, using isotopic and hydrochemical approaches.Water $\mathbf{8}, 1$. 2016.

35. VYSTAVNA Y., DIADIN D., GRYNENKO V., YAKOVLEV V., VERGELES Y., HUNEAU F., ROSSI P. M., HEJZLAR J., KNÖLLER K.. Determination of dominant sources of nitrate contamination in transboundary (Russian Federation/Ukraine) catchment with heterogeneous land use. Environ Monit Assess 189, $509,2017$.

36. MENG Z., YANG Y, QIN Z., HUANG L. Evaluating temporal and spatial variation in nitrogen sources along the lower reach of fenhe river (Shanxi Province, China) using stable isotope and hydrochemical tracers. Water $\mathbf{1 0}$, (231), 2, 2018.

37. HOSONO T., TOKUNAGA T., KAGABU M., NAKATA H., ORISHIKIDA T., LIN I., SHIMADA J. The use of ${ }^{15} \mathrm{~N}$ and ${ }^{18} \mathrm{O}$ tracers with an understanding of groundwater flow dynamics for evaluating the origins and attenuation mechanisms of nitrate pollution. Water Res. 47, 2661, 2013.

38. FENECH C., ROCK L., NOLAN K., TOBIN J., MORRISSEY A. The potential for a suite of isotope and chemical markers to differentiate sources of nitrate contamination: a review. Water Res. 46, 2023, 2012

39. HOSONO T., WANG C.-H., UMEZAWA Y., NAKANO T., ONODERA S., NAGATA T., YOSHIMIZU C., TAYASU I., TANIGUCHI M. Multiple isotope $(\mathrm{H}, \mathrm{O}, \mathrm{N}, \mathrm{S}$ and $\mathrm{Sr}$ ) approach elucidates complex pollution causes in the shallow groundwater of the Taipei urban area. J Hydrol. 379, 23, 2011

40. LI D., JIANG X., ZHENG B. Using $15 \mathrm{~N}$ and 180 Signatures to Evaluate Nitrate Sources and Transformations in Four Inflowing Rivers, North of Taihu Lake. Water, 9 (345), 2, 2017.

41. SEBILO M., MAYER B, NICOLARDOT B., PINAY G., MARIOTTIA A. Long-term fate of nitrate fertilizer in agricultural soils. Proc Natl Acad Sci. Nov 5; 110 (45), 18185, 2013.

42. ZHANG Y., LI F., ZHANG Q., LI J., LIU Q. Tracing nitrate pollution sources and transformation in surfaceand ground-waters using environmental isotopes. Sci Total Environ 490, 213, 2014

43. SAVARD M.M., SOMERS G., SMIRNOFF A., PARADIS D., BOCHOVE E., LIAO S. Nitrate isotopes unveil distinct seasonal $\mathrm{N}$-sources and the critical role of crop residues in groundwater contamination. J Hydrol 381, 134, 2010 .

44. DEMIREL Z., ÖZER Z., ÖZER O. Investigation and modeling of water quality of Göksu River (Cleadnos) in an international protected area by using GIS. J. Geogr. Sci., 21 (3), 429, 2011 
45. KARABULUT M. An examination of temporal changes in Göksu delta lakes using different remote sensing techniques. The Journal of International Social Research. 8 (37), 347, 2015.

46. TÜRKMEN M., TÜRKMEN A., TEPE Y. Comparison of metals in tissues of fish from Paradeniz Lagoon in the coastal area of northern east Mediterranean. Bull Environ Contam Toxicol. 87 (4), 381, 2011.

47. ROSELLI L., STANCA E., LUDOVISI A., DURANTE G., SOUZA J.S.D., DURAL M., ALP T., BULENT S., GJONI V., GHINIS S., BASSET A...Multi-scale biodiverity patterns in phytoplankton from coastal lagoons: the Eastern Mediterranean. Transit. Waters Bull. 7 (2), 202, 2013.

48. ALP M.T., FAKIOĞLU Y.E., ÖZBAY Ö., KOÇER M. A.T. A study on water quality and trophic state of Akgöl Lagoon (Mersin, Turkey), Aquat Ecosyst Health Manag, 19 (1), 58, 2016.

49. WATER POLLUTION CONTROL REGULATIONS (WPCR). Number: 25687. Ministry of Environment and Forests, Ankara, 2018.

50. US EPA (United States Environmental Protection Agency). National Primary Drinking Water Regulations. EPA 816-F-09-004. 2009.
51. XING M., LIU W. Using dual isotopes to identify sources and transformations of nitrogen in water catchments with different land uses, Loess Plateau Of China. Environ Sci Pollut R 23, 388, 2016.

52. NISI B., RACO B., DOTSIKA E. Groundwater Contamination Studies by Environmental Isotopes: A review. In: Scozzari A., Dotsika E. (eds) Threats to the Quality of Groundwater Resources. The Handbook of Environmental Chemistry, vol 40. Springer, Berlin, Heidelberg. 2014.

53. ZHOU Y., LI W. A review of regional groundwater flow modeling. Geosci Front. 8 (2), 205, 2011.

54. AMIRABDOLLAHIAN M., DATTA B. Identification of contaminant source characteristics and monitoring network design in groundwater aquifers: an overview. Journal of Environmental Protection, 4 (5A), 26, 2013.

55. GUPTA T., AGARWAL A.K., AGARWAL R.A., LABHSETWAR N.K. Environmental contaminants: measurement, modeling and control. Springer, 431, 2017.

56. EL-ZEHAIRY A.A., LUBCZYNSKI M.W., GURWIN J. Interactions of artificial lakes with groundwater applying an integrated MODFLOW solution. Hydrogeol J. 26, 109, 2018. 